\title{
ABCB4 Gene
}

National Cancer Institute

\section{Source}

National Cancer Institute. ABCB4 Gene. NCI Thesaurus. Code C123862.

This gene is involved in the cellular export of organic anions and drugs and the intramembrane transport of phosphatidylcholine. 